\title{
PENGARUH MODEL PEMBELAJARAN DAN GAYA BELAJAR TERHADAP HASIL BELAJAR MATEMATIKA
}

\author{
Rosmaini Sembiring ${ }^{1}$ dan Julaga Situmorang ${ }^{2}$ \\ SMA Negeri 1 Blang Pegayon Kabupaten Gayo Luwes ${ }^{1}$ dan Universitas Negeri Medan ${ }^{2}$ \\ rosmainisembiring@yahoo.com ${ }^{l}$
}

\begin{abstract}
Abstrak: Penelitian ini bertujuan untuk mengetahui : (1) Perbedaan hasil belajar matematika antara siswa yang diajar dengan model pembelajaran inkuiri dan hasil belajar matematika siswa yang diajar dengan model pembelajaran masyarakat belajar, (2) Perbedaan hasil belajar matematika antara siswa yang memiliki gaya belajar visual dan yang memiliki gaya belajar auditorial, (3) interaksi antara model pembelajaran dan gaya belajar terhadap hasil belajar matematika. Metode penelitian menggunakan metode quasi eksperimen dengan desain penelitian faktorial $2 \times 2$. Teknik analisis data menggunakan ANAVA dua jalur pada taraf signifikan $\alpha=$ 0,05. Hasil penelitian menunjukkan bahwa: (1) hasil belajar matematika yang diajar dengan model pembelajarn inkuiri lebih tinggi daripada model pembelajaran masyarakat belajar, dengan $F_{\text {hitung }}$ $=4,50>F_{\text {tabel }}=3,97,(2)$ hasil belajar matematika siswa yang memiliki gaya belajar visual lebih tinggi daripada gaya belajar auditorial, dengan $F_{\text {hitung }}=15,22>F_{\text {tabel }}=3,97$, (3) terdapat interaksi antara model pembelajaran dan gaya belajar terhadap hasil belajar matematika, dengan $F_{\text {hitung }}=28,50>F_{\text {tabel }}=3$,97. Perhitungan uji lanjut dengan uji Scheffe menunjukkan perbedaan yang signifikan pada hasil belajar matematika antara model pembelajaran inkuiri dan masyarakat belajar, begitu pula anatara gaya belajar visual dan gaya belajar auditorial.
\end{abstract}

Kata Kunci: model pembelajaran, gaya belajar, hasil belajar matematika

Abstract: This study aims to determine: (1) The difference in the results of learning mathematics between students who are taught by inquiry learning model and the results of learning mathematics students who are taught by learning model learning community, (2) The difference in the results of learning mathematics between students who have a visual learning style and who have auditory learning styles, (3) the interaction between learning models and learning styles on mathematics learning outcomes. The research method using quasi-experimental design with $2 \times 2$ factorial study data were analyzed using ANOVA two lines at significant level $\alpha=0.05$. The results showed that: (1) the results of studying mathematics taught by models higher than pembelajarn inquiry learning model learning community, with $F_{c}=4.50>F_{t}=3.97$, (2) the results of learning mathematics students who have a visual learning style higher than auditory learning style, with $F_{c}=15.22>F_{t}$ $=3.97$, (3) there is interaction between learning models and learning styles on mathematics learning outcomes, with $F_{c}=28.50>F_{t}=3.97$. Further test calculations with Scheffe test showed a significant difference in learning outcomes between the mathematical model of inquiry learning and learning communities, as well as learning styles anatara visual and auditory learning styles.

Keywords: learning models, learning styles, learning outcomes mathematics

\section{PENDAHULUAN}

Program studi IPA pada tingkat SMA bertujuan untuk mengembangkan potensi peserta didik agar memiliki karakter, kompetensi, dan kecakapan hidup melalui pemahaman prinsi-prinsip alam. Agar siswa program IPA dapat mengembangkan segala potensi yang dimilikinya, maka kurikulum program studi IPA memuat sejumlah mata pelajaran umum, mata pelajaran program studi dan mata pelajaran pendukung meliputi pendidikan agama, kewarganegaraan, bahasa dan sastra Indonesia, bahasa Inggris, matematika, kesenian, pendidikan jasmani, geografi, fisika, kimia, biologi, teknologi informasi dan komunikasi, serta keterampilan.

Mata pelajaran matematika sebagai salah satu mata pelajaran yang harus dipelajari pada semua program studi di SMA bertujuan mengembangkan kemampuan siswa untuk 
berpikir kritis, sistematis, logis, kreatif, dan bekerjasama secara efektif sehingga mampu bersaing dalam kehidupan modern yang kompetitif saat ini. Kecakapan atau kemahiran matematika yang diharapkan dapat tercapai dalam pembelajaran matematika dituangkan dalam standar kompetensi berupa: (1) menunjukkan pemahaman konsep matematika yang dipelajari, menjelaskan keterkaitan antara konsep, dan mengaplikasikan konsep atau algoritma secara luwes, akurat, efisien, dan tepat, dalam pemecahan masalah, (2) memiliki kemampuan mengkomunikasikan gagasan dengan simbol, tabel, grafik, atau diagram untuk memperjelas keadaan atau masalah, (3) menggunakan penalaran pada pola, sifat atau melakukan manipulasi matematika dalam membuat generalisasi, menyusun bukti, atau menjelaskan gagasan dan pernyataan matematika, (4) menunjukkan kemampuan model dalam membuat atau merumuskan, menafsirkan, dan menyelesaikan model matematika dalam pemecahan masalah, dan (5) memiliki sikap menghargai kegunaan matematika dalam kehidupan (Departemen Pendidikan Nasional, 2006). Di samping itu melalui pembelajaran matematika diharapkan siswa mampu bersikap peka, tanggap, dan berperan aktif dalam menggunakan konsep matematika untuk memecahkan masalah di lingkungannya.

Menurut Bruner (dalam Sudjana, 2001) belajar yang terbaik haruslah merupakan proses berpikir, dan berpikir pada hakikatnya merupakan proses kognitif, sehingga manusia membedakan, memilih, dan menentukan objek, serta kemampuan untuk mengkonstruksi kembali informasi yang telah diterima. Sedangkan hakikat belajar menurut Dahar (1989) adalah adanya perubahan tingkah laku. Perubahan tingkah laku sebagai hasil belajar ditunjukkan dengan berbagai aspek seperti perubahan pengetahuan, pemahaman, persepsi, motivasi, dan gabungan dari aspek-aspek tersebut. Sependapat dengan hal ini Tirtarahardja dan Sula (2000) mengemukakan bahwa belajar adalah sebagai aktivitas pengembangan diri melalui pengalaman, bertumpu pada kemampuan pada diri siswa di bawah bimbingan guru. Belajar merupakan perubahan seluruh tingkah laku individu secara bertahap yang relatif menetap sebagai hasil pengalaman dan interaksi dengan lingkungan yang melibatkan proses kognitif.
Fungsi matematika menurut Nurhadi (2004) adalah mengembangkan kemampuan menghitung, mengukur, menurunkan dan menggunakan rumus matematika yang diperlukan dalam kehidupan sehari-hari melalui materi pengukuran dan geometri, aljabar dan trigonometri, matematika juga berfungsi mengembangkan kemampuan mengkomunikasikan gagasan dengan bahasa melalui model matematika yang dapat berupa kalimat dan persamaan matematika, diagram, grafik, atau tabel. Topik-topik pembahasan di dalam mata pelajaran matematika tersusun secara hirarkis dan ketat, mulai dari yang mendasar atau yang termudah sampai kepada yang paling sukar, oleh karenanya menurut Hudojo (1983) mempelajari matematika haruslah bertahap serta mendasar kepada pengalaman belajar yang lalu.

Romizowski (1981) menyatakan bahwa hasil belajar diperoleh dalam bentuk pengetahuan dan keterampilan. Pengetahuan dikelompokkan pada empat kategori yaitu: (1) fakta, merupakan pengetahuan tentang objek nyata, asosiasi dari kenyataan, dan informasi verbal dari suatu objek, peristiwa atau manusia; (2) konsep, merupakan pengetahuan tentang seperangkat objek konkrit atau definisi; (3) prosedur, merupakan pengetahuan tentang tindakan demi tindakan yang bersifat linier dalam mencapai suatu tujuan; dan (4) prinsip, merupakan pernyataan mengenai hubungan dari dua konsep atau lebih. Sedangkan hasil belajar dalam bentuk keterampilan juga dikelompokkan dalam empat kategori yaitu: (1) keterampilan kognitif, merupakan keterampilan seseorang dalam menggunakan pikiran untuk mengambil keputusan atau memecahkan masalah; (2) akting, yaitu keterampilan fisik atau teknik seperti olah raga atau terampil dalam mengerjakan sesuatu; (3) reaksi, merupakan keterampilan bereaksi terhadap suatu situasi dalam arti nilai-nilai emosi dan perasaan dengan orang lain untuk mencapai suatu tujuan seperti komunikasi, persuasi, dan pendidikan

$$
\text { Sedangkan Reigeluth }
$$

menyatakan hasil pembelajaran harus memiliki efektivitas, efisiensi dan daya tarik. Efektivitas diukur dari tingkat pencapaian hasil belajar yang diperoleh oleh peserta didik, baik secara kualitas maupun kuantitas. Secara kualitas hasil belajar menunjukkan kebermaknaan isi bahan yang dipelajari dalam kehidupan sehari-hari, sedangkan kuantitas menunjukkan jumlah variasi hasil belajar yang dapat dicapai oleh 
pebelajar. Efesiensi diukur berdasarkan waktu yang dibutuhkan pebelajar untuk belajar, dalam arti semakin sedikit waktu yang dibutuhkan pebelajar untuk memahami isi materi pelajaran, maka semakin efisien hasil belajar yang diperoleh. Sedangkan daya tarik diukur dari ada tidaknya kecenderungan pebelajar termotivasi untuk belajar lebih lanjut dalam arti mengembangkan wawasan berdasarkan hasil belajar yang telah diperoleh.

Menurut Tinggih dalam Russefendi (1980) secara etimologis matematika merupakan pengetahuan yang diperoleh dengan penalaran. Karakteristik matematika yang membedakannya dengan bidang ilmu lain adalah bahwa matematika lebih menekankan hasil aktivitas dalam dunia rasio (penalaran), sedangkan dalam ilmu lain umumnya lebih menekankan hasil observasi atau eksperimen di samping penalaran. Agar konsep-konsep matematika yang telah terbentuk dapat dipahami orang lain dan dapat dengan mudah dimanipulasi secara tepat, maka digunakan notasi dan istilah yang cermat yang disepakati bersama secara universal dan dikenal dengan bahasa matematika. Matematika terbentuk sebagai hasil pemikiran manusia yang berhubungan dengan ide, proses, dan penalaran (Ruseffendi, 1980).

Untuk mengetahui apakah peserta didik telah menguasai sejumlah kompetensi sebagai hasil dari belajar, perlu dilakukan evaluasi. Evaluasi digunakan sebagai alat kontrol untuk mengetahui sejauh mana seseorang telah mencapai hasil belajar. Menurut Gronlund (1985) untuk melihat hasil belajar yang telah dicapai siswa, setelah siswa melakukan belajar dapat dilakukan melalui tes atau bentuk evaluasi yang diberikan secara periodik. Syah (1996) mengemukakan tes hasil belajar adalah alat ukur yang digunakan untuk menentukan taraf keberhasilan suatu program pengajaran.

Menurut Joyce dan Weil (2009) pengertian model adalah suatu rencana atau pola yang digunakan dalam menyusun kurikulum, mengatur materi pelajaran, dan memberi petunjuk kepada pengajar di kelas dalam setting pembelajaran atau setting lainnya. Masih menurut Joyce dan Weil (2009) jika dikaitkan dengan pembelajaran istilah model digunakan untuk dua alasan penting, yaitu: (1) model mempunyai makna yang lebih luas daripada suatu strategi, metode, atau prosedur, istilah model pembelajaran mencakup suatu pendekatan pembelajaran yang luas dan menyeluruh, dan (2) model pembelajaran dapat berfungsi sebagai sarana komunikasi yang penting berkaitan dengan apa yang dibicarakan di dalam kelas.

Pengelolaan pembelajarn mengacu kepada suatu upaya untuk mengatur aktivitas pembelajaran berdasarkan konsep dan prinsip pembelajaran yang tidak terlepas dari prinsipprinsip belajar bagi siswa. Hal ini mencakup (1) perhatian dan motivasi, (2) keaktifan, (3) keterlibatan langsung/ berpengalaman, (4) pengulangan, (5) tantangan, (6) balikan dan penguatan, serta (7) perbedaan individual (Dimyati dan Mudjiono, 2002).

Istilah model pembelajaran memiliki unsur-unsur: (1) sintakmatik, (2) sistem sosial, (3) prinsip reaksi, (4) sistem pendukung, dan (5) dampak instruksional dan pengiring. Sintakmatik merupakan tahap-tahap dari kegiatan model (Joyce dan Weil, 2009). Sintak suatu model pembelajaran menggambarkan keseluruhan urutan alur langkah yang pada umumnya diikuti oleh serangkaian kegiatan apa yang perlu dilakukan guru atau siswa, urutan kegiatan-kegiatan yang dilakukan, dan tugastugas khusus yang perlu dilakukan siswa. Lingkungan belajar dari tiap-tiap model pembelajaran biasanya berbeda. Setiap model pembelajaran memberikan peran yang berbeda kepada siswa, pada ruang fisik, dan pada sistem sosial kelas.

Melalui model pembelajaran tertentu siswa dapat diarahkan untuk mencapai tujuan pembelajaran. Menurut Dahlan (1984) model pembelajaran sebenarnya tidaklah dimaksudkan untuk membantu semua jenis belajar atau untuk melaksanakan berbagai gaya belajar. Penciptaan model pembelajaran didasari kepada asumsi bahwa hanya ada model belajar tertentu yang cocok untuk ditangani dengan model mengajar tertentu. Pemilihan model pembelajaran harus disesuaikan dengan tujuan pembelajaran, karakteristik mata pelajaran, dan karakteristik siswa.

Model pembelajaran diterapkan berdasarkan teori pembelajaran. Menurut Snelbecker (1974) ada beberapa kegunaan teori, yaitu: (1) teori diperlukan untuk mensistematiskan hasil penelitian agar gejalagejala yang semula tidak diketahui maknanya dapat dipahami, (2) teori berfungsi menimbulkan hipotesis, dengan demikian dapat memberitahu ke arah mana perhatian harus diberikan dan di mana harus dicari jawaban atas pertanyaan yang timbul, (3) teori dapat 
digunakan untuk membuat prediksi, sehingga tidak hanya memberikan jawaban atas pertanyaan yang ada sekarang, melainkan juga menunjukkan hal-hal yang dapat diharapkan, (4) teori dapat digunakan untuk menjelaskan gejala yang dihadapi, atau dengan kata lain melalui teori dapat dijelaskan kenapa sesuatu gejala terjadi. Teori pembelajaran merupakan suatu set prinsip yang terintegrasi yang memberikan petunjuk untuk mengatur kondisi guna mencapai tujuan pembelajaran.

Inkuiri yang dalam bahasa Inggris inkuiri, berarti mempertanyakan, pemeriksaan atau penyelidikan. Dengan melakukan penyelidikan, siswa akhirnya dapat memperoleh suatu penemuan. Model ini berkembang dari ide John Dewey yang terkenal dengan "'problem solving method" atau metode pemecahan masalah. Bruner dalam Hasibuan dan Moejiono (1993) yang mengemukakan bahwa pencarian (inkuiri) mengandung makna sebagai berikut: (1) dapat membangkitkan potensi intelektual siswa karena seseorang hanya dapat belajar dan mengembangkan pikirannya jika ia menggunakan potensi inlelektualnya untuk berpikir; (2) siswa yang semula memperoleh extrinsic reward dalam keberhasilan belajar (mendapat nilai yang baik), dalam pendekatan inkuiri akan dapat memperoleh intrinsic reward (kepuasan diri), (3) siswa dapat mempelajari heuristik (mengolah pesan atau informasi) dari penemuan, artinya bahwa cara untuk mempelajari teknik penemuan ialah dengan jalan memberikan kesempatan kepada siswa untuk mengadakan penelitian sendiri, dan (4) dapat menyebabkan ingatan bertahan lama sampai internalisasi pada diri siswa.

Menurut Schuman (dalam Wardani, 2000) anak memiliki motivasi alamiah untuk meneliti atau berinkuiri. Oleh karena itu inkuiri membutuhkan partisipasi aktif dari siswa untuk meneliti sendiri secara ilmiah masalah yang dihadapi. Ini tidaklah berarti bahwa dengan inkuiri siswa akan dididik menjadi seorang ilmuan, karena inkuiri mencoba membawa siswa ke dalam situasi yang memberikan kesempatan untuk menggunakan apa yang telah diketahui dan menyadari apa yang mereka lakukan itu adalah hasil perolehan mereka sendiri dan bukan perolehan gurunya. Oleh karena itu, sasaran utama model ini adalah keterlibatan siswa secara maksimal dalam proses pembelajaran.

Amien (1987) menyatakan bahwa inkuiri learning memberikan waktu bagi siswa untuk mengasimilasi dan mengakomodasi informasi, mendorong siswa untuk berpikir inisiatif dan merumuskan hipotesisnya sendiri. Proses belajar meliputi semua aspek yang menunjang siswa menuju ke pembentukan manusia seutuhnya, misalnya; di dalam situasi proses inkuiri, siswa tidak hanya belajar tentang konsep-konsep dan prinsip-prinsip. tetapi ia juga mengalami proses belajar tentang tentang pengarahan diri sendiri, tanggungjawab, komunikasi sosial dan sebagainya.

Menurut Joyce dan Weil (2009) model pembelajaran inkuiri merupakan salah satu model yang termasuk dalam kelompok model pengajaran memproses informasi (the information-processing family). Model pengajaran memproses informasi menekankan cara-cara dalam meningkatkan dorongan alamiah manusia untuk membentuk makna tentang dunia dengan memeperoleh dan mengolah data, merasakan masalah-masalah dan menghasilkan solusi-solusi yang tepat, serta mengembangkan konsep dan bahasa untuk menstransfer solusi atau data tersebut. Dari beberapa model yang melibatkan siswa dalam penelitian ilmiah (scientific inkuiri) yang diekmukakan Joyce dan Weil yang dijadikan sebagagai tolak ukur dan akar perkembangan model inkuiri adalah kajian kurikulum ilmu biologi (biological scientific curriculum study/BSCS). Struktur pengajaran model ini pada dasarnya meliputi eleman-elemen atau tahapan-tahapan: (1) siswa disajikan masalah atau bidang penelitian, yang meliputi metodelogi-metodologi yang digunakan dalam pemecahan masalah tersebut, (2) masalah mulai disusun sehingga siswa dapat mengidentifikasi masalah dalam penelitian tersebut, (3) siswa mengajukan berbagai asumsi dan pendapat tentang masalah tersebut, sehingga dapat mengidentifikasi kesulitan yang ditemui dalam prosedur penemuan, dan (4) siswa diminta mengajukan kembali asumsi dan pendapat tentang cara-cara memperjelas kesulitan tersebut, dengan merancang kembali ujicoba, mengolah data dengan cara yang berbeda, menghasilkan data, mengembangkan konstrukkonstruk dan sebagainya.

Selanjutnya Joyce dan Weil (2009) menyatakan kondisi-kondisi umum yang merupakan syarat bagi timbulnya kegiatan inkuiri bagi siswa, yaitu: (a) aspek sosial di dalam kelas dan suasana terbuka yang mengundang siswa berdiskusi. Hal ini menuntut adanya suasana bebas (permisif) di dalam kelas, 
dimana setiap siswa tidak merasakan adanya tekanan atau hambatan untuk mengemukakan pendapatnya, (b) inkuiri berfokus pada hipotesis. Siswa perlu menyadari bahwa pada dasarnya semua pengetahuan bersifat tentatif. Tidak ada kebenaran yang bersifat mutlak, kebenarannya selalu bcrsifat sementara. Adanya berbagai sudut pandang yang berbeda di antara siswa, maka sedapat mungkin melakukan variasi penyelesaian masalah sehingga inkuiri bersifat open ended. Inkuiri bersifat open ended jika ada berbagai kesimpulan yang berbeda dari masing-masing siswa dengan argumen yang benar, dan (c) penggunaan fakta sebagai evidensi. Di dalam kelas dibicarakan validitas dan reliabilitas tentang fakta sebagaimana dituntut dalam pengujian hipotesis pada umumnya.

Masih menurut Joyce dan Weil (2009) model pembelajaran inkuiri akan efektif manakala: (1) guru mengharapkan siswa dapat menemukan sendiri jawaban dari suatu permasalahan yang ingin dipecahkan. Dengan demikian dalam model inkuiri penguasaan materi pelajaran bukan sebagai tujuan utama pembelajaran, akan tetapi yang lebih dipentingkan adalah proses belajar, (2) jika bahan pelajaran yang akan diajarkan tidak berbentuk fakta atau konsep yang sudah jadi, akan tetapi sebuah kesimpulan yang perlu pembuktian, (3) jika proses pembelajaran berangkat dari rasa ingin tahu siswa terhadap sesuatu, (4) jika guru akan mengajar pada sekelompok siswa yang rata-rata memiliki kemauan dan kemampuan berpikir. Model inkuiri akan kurang berhasil diterapkan kepada siswa yang kurang memiliki kemampuan untuk berpikir, (5) jika jumlah siswa yang belajar tak terlalu banyak sehingga bisa dikendalikan oleh guru, dan (6) jika guru memiliki waktu yang cukup untuk menggunakan pendekatan yang berpusat pada siswa.

Kegiatan belajar inkuiri adalah kegiatan mental intelektual dan sosial emosional, keterarahan kegiatan secara logis dan sistematis pada tujuan pembelajaran, pengembangan sikap percaya pada diri sendiri (self belief), pada diri siswa tentang apa yang ditemukan dalam proses inkuiri. Menurut Joyce dan Weil (2009) belajar dengan cara menemukan sendiri dapat dipercaya dalam mengembangkan kemandirian, anak-anak mempunyai rasa ingin tahu untuk tumbuh, belajar dengan menemukan merupakan bekal dalam menggali semangat anak, memberikan bimbingan secara khusus sehingga mereka dapat memahami suatu gagasan yang lebih luas.

Pada hakikatnya inkuiri merupakan suatu proses yang bermula dari merumuskan masalah, mengembangkan hipotesis, mengumpulkan bukti, menguji hipotesis, dan menarik kesimpulan sementara, menguji kesimpulan sementara supaya sampai pada kesimpulan pada taraf tertentu yang diyakini oleh siswa yang bersangkutan. Dengan demikian, penggunaan model ini harus direncanakan guru sedemikian rupa agar siswa dapat terlibat langsung dalam kegiatan-kegiatan dan pengalaman-pengalaman "ilmiah" menemukan konsep-konsep dan prinsip-prinsip melalui proses mentalnya sendiri.

Masyarakat Belajar atau Learning Community merupakan bagian dari model pembelajaran kontekstual yang mengarahkan siswa pada sejumlah kegiatan yang mengasumsikan bahwa secara natural pikiran mencari makna konteks sesuai dengan situasi nyata lingkungan seseorang. Kontekstual merupakan sebuah pendekatan pembelajaran yang mengakui dan menunjukkan kondisi alamiah dari pengetahuan. Joyce dan Weil (2009) mengelompokkan masyarakat belajar dalam kelompok model pengajaran sosial. Model-model sosial dibangun untuk mendapatkan keuntungan dari fenomena dengan cara membuat komunitas pembelajaran. Inti dari model pembelajaran ini adalah bekerjasama dalam mempelajari hal-hal yang sifatnya akademis dan berupaya untuk mempersiapkan peserta didik untuk menjadi warga Negara yang baik serta membentuk kehidupan social yang memuaskan.

Menurut Trianto (2007), masyarakat belajar mengarahkan siswa untuk saling berbagi dengan teman dalam satu kelompok. Fungsi guru hanyalah sebagai fasilitator. Masyarakat belajar dapat terjadi apabila terdapat proses komunikasi dua arah. Dalam masyarakat belajar dua kelompok atau lebih yang terlibat dalam komunikasi pembelajaran saling belajar satu sama lain. Menurut Nurhadi (2004) masyarakat belajar sebagai bagian pembelajaran kontekstual memenuhi beberapa syarat sebagai berikut: (1) sekelompok orang yang terikat dalam kegiatan belajar, (2) Bekerjasama dengan orang lain lebih baik daripada belajar sendiri, (3) saling tukar pengalaman (4) berbagi ide, (5) berbicara dan berbagi pengalaman dengan orang lain. (6) ada kerjasama untuk memecahkan masalah, (7) hasil pembelajaran 
secara kelompok akan lebih baik daripada belajar sendiri (9) ada fasilitator/guru yang memandu proses belajar dalam kelompok.

Menurut McMillan dan Chavis (1986) ada empat faktor utama yang didefinisikan rasa kebersamaan dalam masyarakat belajar, yaitu: (1) kenggotaan, (2) pengaruh, (3) pemenuhan kebutuhan individu, dan (4) mengalami kegiatan dan hubungan emosional. Jadi, para siswa belajar masyarakat harus merasakan rasa kesetiaan dan seterusnya keanggotaan yang mendorong keinginan mereka untuk tetap berkerja dan membantu orang lain, juga hal-hal yang dilakukan dalam anggota kelompok harus mempengaruhi apa yang terjadi di kelompok tersebut. Selain itu dalam masyarakat belajar harus diberikan kesempatan kepada para peserta untuk memenuhi kebutuhan-kebutuhan khusus (pemenuhan) dengan mengungkapkan pendapat pribadi, meminta bantuan atau infoemasi spesifik dan berbagi cerita keladian dengan isu tertentu disertakan (hubungan emosional) dan pengelaman emosional.

Menurut Trianto (2007) dalam masyarakat belajar hasil belajar yang diperoleh merupakan hasil sharing dengan teman. Dengan saling berbagi informasi, siswa akan memiliki suatu keterikatan social dengan teman dalam satu kelompoknya. Lingkungan belajar untuk pembelajaran masyarakat belajar dicirikan oleh proses demokrasi dan peran aktif siswa dalam menentukan bagaimana mempelajari sesuatu (Departemen pendidikan nasional, 2005). Tingkah laku siswa juga tidak boleh dikelola secara ketat dalam kelompoknya, model ini sangat berguna membantu siswa memahami konsep-konsep sulit, membantu siswa menumbuhkan kemampuan kerjasama, berpikir kritis, dan kemampuan membantu teman.

DePorter \& Hernacki (1992) mengatakan bahwa gaya belajar adalah kunci untuk mengembangkan kinerja dalam pekerjaan, di sekolah, dan dalam situasi-situasi antar pribadi. Pada awal pengalaman belajar, salah satu diantara langkah-langkah pertama kita adalah mengenali modalitas seseorang sebagai modalitas visual, auditorial, atau kinestetik (VA-K). Madden (2002) mengemukakan bahwa "Setiap orang unik. Sebagian orang belajar terutama dengan menggunakan keterampilan auditori untuk memproses informasi yang didengar. Sebagian lagi lebih menggunakan keterampilan visual untuk memproses informasi yang sama." Pembelajar visual suka melihat gambar atau informasi dalam bentuk tulisan.
Tetapi sebagian lagi suka menggunakan keterampilan fisik atau pengalaman. Seorang pembelajar fisik, yang juga disebut pembelajar kinestetis, suka menyentuh peralatan dan belajar dengan baik melalui peranan peragaan.

Gunawan (2004) mengemukakan bahwa pada umumnya, orang jarang menggunakan hanya satu gaya belajar. Jarang ada orang yang hanya belajar secara visual, atau hanya secara auditori, atau hanya secara kinestetik. Biasanya akan ada kombinasi antara visual dan auditori, atau auditori dan kinestetik, atau bahkan kombinasi antara ketiga gaya belajar ini. Dari hasil penelitian diketahui bahwa jumlah orang yang belajar secara visual 27\%, auditori 34\%, dan kinestetik 39\% (Gunawan, 2004) Hal ini menjawab pertanyaan mengapa banyak sekali siswa yang mengalami kesulitan belajar.Mengenali modalitas belajar orang lain adalah kunci penting untuk menghasilkan presentasi yang lebih efektif. Misalnya, bila kita tahu bahwa atasan anda adalah orang visual, akan lebih memungkinkan bagi kita untuk menyampaikan maksud jika kita menggunakan material visual, seperti slide dan makalah, dalam suatu presentasi.

Meskipun ada banyak pendekatan dalam hal gaya belajar, hal yang paling penting adalah bagaimana pengetahuan mengenai gaya belajar ini dapat digunakan untuk membantu kita memaksimalkan proses pembelajaran, karena : (1) mengetahui bahwa gaya belajar siswa (sebagai orang tua atau guru) mungkin justru akan jadi penghambat dalam mencapai proses pembelajaran yang efektif, (2) mengerti gaya belajar siswa, sehingga kita tidak terlalu terpaku pada satu gaya saja, (3) mengakomodasikan gaya belajar yang berbeda, tetapi tidak mencoba untuk terlalu memaksakan diri menuruti semuanya, dan (4) mulai menyadari bahwa gaya belajar patut diperhatikan dengan sungguh-sungguh.(Gunawan, 2004).

Rumusan masalah dalam penelitan ini adalah: (1) Apakah hasil belajar matematika siswa yang diajar dengan model pembelajaran inkuiri lebih tinggi daripada hasil belajar siswa yang diajar dengan model pembelajaran masyarakat belajar?; (2) Apakah hasil belajar matematika siswa yang memiliki gaya belajar visual lebih tinggi daripada siswa yang memiliki gaya belajar auditorial?; dan (3) Apakah terdapat interaksi antara model pembelajaran dengan gaya belajar terhadap hasil 


\section{METODE}

Penelitian dilaksanakan di SMA Negeri 1 Blang Pegayon. Populasi dalam penelitian ini adalah seluruh siswa kelas XI IPA SMA Negeri 1 Blang Pegayon, yang terdiri dari 4 kelas. Kesemua populasi pada masing-masing kelas diasumsikan memiliki karakteristik yang hampir sama berdasarkan kemampuan akademik siswa, karena siswa yang duduk di masing-masing kelas disaring berdasarkan nilai rapot kelas $X$ (sepuluh) untuk mata pelajaran matematika, fisika, biologi, dan kimia yang harus memiliki rata-rata nilai ketuntasan belajar 65. Pemilihan siswa pada masing-masing kelas dipilih secara acak tanpa ada kelas unggulan atau bukan unggulan.

Untuk penarikan sampel dilakukan secara acak melalui undian yakni dari 4 (empat) kelas diperoleh 2 (dua) kelas eksperimen. Dasar penarikan sampel pada kedua kelas ini didasarkan pada asumsi kesamaan pada tingkat kelas tanpa adanya kelas unggulan, usia ratarata siswa, kemampuan akademik rata-rata siswa yang sama, serta kurikulum dan fasilitas pembelajaran yang sama pula. Teknik pengambilan sampel dilakukan dengan teknik cluster random sampling, dari 2 (dua) kelas yang telah terpilih sebagai sampel penelitian, selanjutnya melalui pengundian maka pada kelas XI IPA 1 terpilih sebagai kelas yang diajar dengan model pembelajaran masyarakat belajar, sedangkan siswa kelas XI IPA 4 terpilih sebagai kelas yang diberi perlakuan dengan model pembelajaran inkuiri.

Desain penelitian yang digunakan adalah desain faktorial $2 \times 2$, seperti terlihat pada Tabel 1. yang mengelompokkan model pembelajaran inkuiri dengan model pembelajaran masyarakat belajar terhadap gaya belajar visual dan gaya belajar auditorial.

Tabel 1. Desain Faktorial 2 x 2

\begin{tabular}{|l|c|c|}
\hline Maya belajar $(\mathbf{B})$ & Inkuiri $\left(\mathrm{A}_{1}\right)$ & Masyarakat belajar $\left(\mathrm{A}_{2}\right)$ \\
\hline Visual $\left(\mathbf{B}_{1}\right)$ & $\mathrm{A}_{1} \mathrm{~B}_{1}$ & $\mathrm{~A}_{2} \mathrm{~B}_{1}$ \\
\hline Auditorial $\left(\mathrm{B}_{2}\right)$ & $\mathrm{A}_{1} \mathrm{~B}_{2}$ & $\mathrm{~A}_{2} \mathrm{~B}_{2}$ \\
\hline
\end{tabular}

Keterangan :

$\mathrm{A}_{1} \mathrm{~B}_{1}=$ Hasil belajar matematika siswa yang diajar dengan menggunakan model pembelajaran inkuiri pada siswa dengan gaya belajar visual

$\mathrm{A}_{1} \mathrm{~B}_{2}=$ Hasil belajar matematika siswa yang diajar dengan menggunakan model pembelajaran inkuiri pada siswa dengan gaya belajar auditorial.

$\mathrm{A}_{2} \mathrm{~B}_{1}=$ Hasil belajar matematika siswa yang diajar dengan menggunakan model pembelajaran masyarakat belajar pada siswa dengan gaya belajar tinggi.

$\mathrm{A}_{2} \mathrm{~B}_{2}=$ Hasil belajar matematika siswa yang diajar dengan menggunakan model pembelajaran masyarakat belajar pada siswa dengan gaya belajar auditorial.

Teknik analisis data dalam penelitian ini menggunakan analisis deskriptif dan analisis inferensial. Teknik analisis deskriptif dimaksudkan untuk mendeskripsikan data penelitian meliputi mean, median, standard deviasi dan kecenderungan data.

Data yang telah diperoleh selanjutnya disajikan dalam bentuk tabel distribusi frekuensi dan histogram. Teknik analisis inferensial digunakan untuk menguji hipotesis penelitian dengan menggunakan teknik analisis varians (ANAVA) dua jalur. Jika hasil penelitian menunjukkan terdapat interaksi antara model pembelajarn dengan gaya belajar, maka dilakukan uji lanjut. Uji lanjut yang digunakan pada penelitian ini adalah uji Scheffe jika n tiap-tiap sel berbeda, dan uji Tuckey jika $\mathrm{n}$ tiap-tiap sel sama. Untuk menggunakan ANAVA dua jalur perlu dipenuhi beberapa syarat yaitu: (1) data yang digunakan harus berdistribusi normal, untuk menguji normalitas data digunakan uji Liliefors, dan (2) data harus memiliki varians populasi homogen, untuk menguji homogenitas varians digunakan uji $\mathrm{F}$ (Fisher) dan uji Bartlet. Semua pengujian dilakukan pada taraf $\alpha=0,05$.

Rumusan hipotesis statistik dalam penelitian ini adalah sebagai berikut: 
Hipotesis pertama :

$$
\begin{array}{ll}
\text { Ho } & : \mu_{A 1} \leq \mu_{A 2} \\
\text { H1 } & : \mu_{A 1}>\mu_{A 2}
\end{array}
$$

Hipotesis kedua :

$$
\begin{array}{ll}
\text { Ho } & : \mu_{B 1} \leq \mu_{B 2} \\
\text { H1 } & : \mu_{B 1}>\mu_{B 2}
\end{array}
$$

Hipotesis ketiga :

$$
\begin{aligned}
& \text { Ho }: A \times B=0 \\
& \text { H1 }: A \times B \neq 0
\end{aligned}
$$

\section{HASIL DAN PEMBAHASAN}

Pengujian hipotesis dilakukan untuk membuktikan kebenaran hipotesis yang telah ditetapkan sehingga diperoleh data apakah hipotesis yang dirancnag dalam sebuah penelitian ditolak atau diterima. Untuk keperluan pengujian hipotesis dengan menggunakan teknik analisis varian dua jalur (ANAVA) faktorial 2x2 dan kemudian dilanjutkan dengan uji lanjut dengan menggunakan uji Scheffe, maka diperlukan harga rata-rata tiap kelompok perlukan sebagai sumber data penelitian, berikut ini disajikan rangkuman data hasil belajar matematika

\begin{tabular}{|c|c|c|c|c|}
\hline \multirow{2}{*}{\multicolumn{2}{|c|}{$\begin{array}{c}\text { RINGKASAN } \\
\text { DATA }\end{array}$}} & \multicolumn{2}{|c|}{ MODEL PEMBELAJARAN } & \multirow{2}{*}{ Total } \\
\hline & & Inkuiri & Masyarakat Belajar & \\
\hline \multirow{2}{*}{$\begin{array}{c}\text { Gaya } \\
\text { Belajar }\end{array}$} & Visual & $\begin{array}{c}\mathrm{n}_{1}=22 \\
\sum \mathrm{P}_{1}=576 \\
\sum \mathrm{X}^{2}{ }_{1}=15178 \\
\overline{\mathrm{X}}_{1}=26,23 \\
\mathrm{~s}^{2}{ }_{1}=5,79\end{array}$ & $\begin{array}{c}\mathrm{n}_{3}=21 \\
\sum \mathrm{P}_{3}=473 \\
\sum \mathrm{X}_{3}{ }_{3}=10775 \\
\overline{\mathrm{X}}_{3}=22,70 \\
\mathrm{~S}^{2}{ }_{3}=5,78\end{array}$ & $\begin{aligned} \mathrm{N}_{1,3} & =43 \\
\sum \mathrm{P}_{1,3} & =1049 \\
\sum \mathrm{X}_{1,3}^{2} & =25953 \\
\overline{\mathrm{X}}_{1,3} & =24,41 \\
\mathrm{~s}_{1,3} & =9,14\end{aligned}$ \\
\hline & Auditorial & $\begin{aligned} \mathrm{n}_{2} & =16 \\
\sum \mathrm{P}_{2} & =338 \\
\sum \mathrm{X}_{2}{ }_{2} & =7230 \\
\overline{\mathrm{X}}_{2} & =21,00 \\
\mathrm{~s}^{2}{ }_{2} & =4,92\end{aligned}$ & $\begin{aligned} \mathrm{n}_{4} & =15 \\
\sum \mathrm{P}_{4} & =351 \\
\sum \mathrm{X}^{2} & =8295 \\
\overline{\mathrm{X}}_{4} & =23,37 \\
\mathrm{~S}_{4}{ }_{4} & =5,41\end{aligned}$ & $\begin{array}{c}\mathrm{N}_{2,4}=31 \\
\sum \mathrm{P}_{2,4}=689 \\
\sum \mathrm{X}_{2,4}^{2}=15525 \\
\overline{\mathrm{X}}_{2,4}=22,00 \\
\mathrm{~s}_{2,4}^{2}=5,79\end{array}$ \\
\hline \multicolumn{2}{|c|}{ Total } & $\begin{array}{c}\mathrm{N}_{1,2}=38 \\
\sum \mathrm{P}_{1,2}=914 \\
\sum \mathrm{X}_{1,2}^{2}=22408 \\
\overline{\mathrm{X}}_{1,2}=23,97 \\
\mathrm{~s}_{1,2}=11,58\end{array}$ & $\begin{array}{c}\mathrm{N}_{3,4}=36 \\
\sum \mathrm{P}_{3,4}=824 \\
\sum \mathrm{X}_{3,4}^{2}=19070 \\
\bar{X}_{3,4}=22,88 \\
\mathrm{~s}_{3,4}=7,95\end{array}$ & $\begin{aligned} \mathrm{N}_{\mathrm{g}} & =74 \\
\sum \mathrm{P}_{\mathrm{g}} & =1738 \\
\sum \mathrm{X}_{\mathrm{g}}^{2} & =41478 \\
\overline{\mathrm{X}}_{\mathrm{g}} & =23,46 \\
\mathrm{~s}_{\mathrm{g}}^{2} & =9,20\end{aligned}$ \\
\hline
\end{tabular}
siswa sebagai sumber pengolahan data untuk pengujian hipotesis. Rangkuman data tersebut dapat dilihat pada Tabel 2 dengan menggunakan analisis deskriptif

Tabel 2. Rangkuman Data Hasil Perhitungan Analisis Deskriptif.

Setelah data tabel 2 diolah dengan ANAVA 2 jalur faktorial $2 \times 2$, maka diperoleh hasil analisis seperti ditunjukkan pada Tabel 3.

Tabel 3. Ringkasan Perhitungan ANAVA Faktorial 2x2

\begin{tabular}{|l|c|c|c|c|c|c|}
\hline \multicolumn{1}{|c|}{ Sumber Varians } & $\mathbf{J K}$ & $\mathbf{d k}$ & $\mathbf{K T}$ & $\mathbf{F}_{\text {hitung }}$ & $\begin{array}{c}\mathbf{F}_{\text {tabet }} \\
(\mathbf{\alpha}=\mathbf{0 , 0 5})\end{array}$ & Ket. \\
\hline Model & 25,04 & 1 & 25,04 & 4,5 & & Signifikan \\
Gaya Berpikir & 84,79 & 1 & 84,79 & 15,22 & 3,97 & Signifikan \\
Interaksi & 158,77 & 1 & 158,77 & 28,5 & & Signifikan \\
\hline Dalam kelompok (galat) & 268,6 & 76 & 5,69 & & & \\
Total & 839,9 & 79 & & & & \\
\hline
\end{tabular}


Pada tabel ringkasan ANAVA untuk model pembelajaran diperoleh $\mathrm{F}_{\text {hitung }}=4,50>$ $\mathrm{F}_{\text {tabel }}=3,97$, untuk gaya belajar $\mathrm{F}_{\text {hitung }}=15,22>$ $\mathrm{F}_{\text {tabel }}=3,97$, dan untuk interaksi diperoleh $\mathrm{F}_{\text {hitung }}$ $=28,50>\mathrm{F}_{\text {tabel }}=3,97$, berdasarkan data-data tersebut, dapat disimpulkan adanya interaksi antara model pembelajaran dengan gaya belajar yang mempengaruhi hasil belajar matematika siswa.

Data yang diperoleh dalam penelitian ini berasal dari sampel yang jumlahnya berbeda untuk setiap sel Anava. Sehingga perlu dilakukan uji Schefee, hasil pengujian dengan menggunakan uji Scheffee dapat dilihat dalam Tabel 4.

Tabel 4. Ringkasan Hasil Pengujian Dengan Menggunakan Uji Scheffe

\begin{tabular}{|c|c|c|c|c|c|}
\hline \multirow{2}{*}{ No } & \multicolumn{2}{|c|}{ Hipotesis Statistik } & \multirow{2}{*}{ F $_{\text {hitung }}$} & \multicolumn{2}{c|}{ F $_{\text {tabel }}$} \\
\cline { 4 - 6 } & & & $\alpha=5 \%$ & $\alpha=1 \%$ \\
\hline 1 & Ho $: \mu_{1}=\mu_{3}$ & Ha $: \mu_{1}>\mu_{3}$ & $\mathbf{3 8 , 4 1}$ & $\mathbf{2 , 7 0}$ & $\mathbf{4 , 3 0}$ \\
\hline 2 & Ho $: \mu_{1}=\mu_{2}$ & Ha $: \mu_{1}>\mu_{2}$ & $\mathbf{2 7 , 5 4}$ & $\mathbf{2 , 7 0}$ & $\mathbf{4 , 3 0}$ \\
\hline 3 & Ho $: \mu_{1}=\mu_{4}$ & Ha $: \mu_{1}>\mu_{4}$ & $\mathbf{7 , 9 3}$ & $\mathbf{2 , 7 0}$ & $\mathbf{4 , 3 0}$ \\
\hline 4 & Ho $: \mu_{2}=\mu_{4}$ & Ha $: \mu_{2}>\mu_{4}$ & $\mathbf{4 , 7 3}$ & $\mathbf{2 , 7 0}$ & $\mathbf{4 , 3 0}$ \\
\hline 5 & Ho $: \mu_{3}=\mu_{4}$ & Ha $: \mu_{3}>\mu_{4}$ & $\mathbf{4 , 1 0}$ & $\mathbf{2 , 7 0}$ & $\mathbf{4 , 3 0}$ \\
\hline 6 & Ho $: \mu_{2}=\mu_{3}$ & Ha $: \mu_{2}>\mu_{3}$ & $\mathbf{2 , 8 5}$ & $\mathbf{2 , 7 0}$ & $\mathbf{4 , 3 0}$ \\
\hline
\end{tabular}

Hasil pengujian hipotesis di atas, menunjukkan adanya interaksi antara model pembelajaran dan gaya belajar terhadap hasil belajar matematika. Interaksi antara model pembelajaran dengan gaya belajar tersebut dapat divisualisasikan dalam bentuk grafis pada gambar 1.

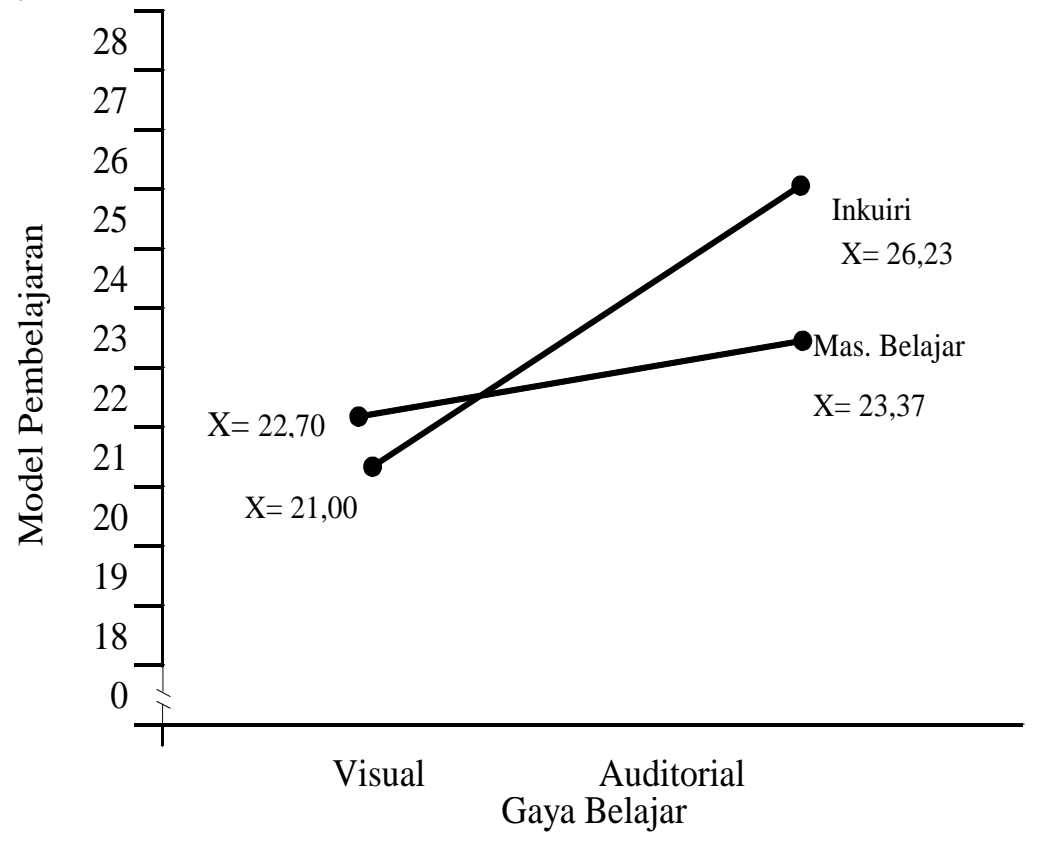

Gambar 1.Interaksi Model Pembelajaran dan Gaya Belajar terhadap Hasil Belajar Matematika.

Berdasarkan hasil pengujian hipotesis ketiga yang menyatakan adanya interaksi antara model pembelajaran dengan gaya belajar, maka perlu dilakukan uji perbedaan rata-rata antara dua proporsi. Gambar 1. menunjukkan pengaruh dan interaksi dari model pembelajaran dan gaya belajar terhadap hasil belajar matematika yang diperoleh siswa, rata-rata hasil belajar matematika siswa yang diajar dengan model inkuiri lebih tinggi dibandingkan dengan model pembelajaran masyarakat belajar. Penelitian ini juga membuktikan faktor gaya belajar sebagai salah satu karakteristik siswa perlu pula diperhatikan karena terbukti bahwa gaya belajar berpengaruh terhadap hasil belajar matematika. 


\section{PEMBAHASAN}

Model inkuiri merupakan bagian pembelajaran kontekstual (contextual teaching ang learning/CTL) yang berasal dari teori pembelajaran konstruktivisme dengan menekankan kemampuan siswa untuk membangun sendiri pengetahuan di dalam benaknya dan peran guru bukan hanya sekedar memberikan pengetahuan kepada siswa melainkan memberikan kemudahan belajar pada siswa dengan memberikan kesempatan kepada siswa untuk menemukan atau menerapkan ide-ide mereka sendiri. Dalam inkuiri, belajar lebih diarahkan kepada kegiatan aktif siswa untuk membangun pengetahuannya. Siswa sendiri yang melakukan penalaran melalui seleksi dan organisasi pengalaman serta mengintegrasikannya dengan apa yang telah diketahui.

Implementasi model inkuiri berupa adanya sejumlah kegiatan yang harus dilakukan siswa, model inkuiri tidak mengharapkan siswa hanya sekedar mendengarkan, mencatat, kemudian menghafal materi pelajaran, akan tetapi melalui model inkuiri siswa aktif berpikir, berkomunikasi, mencari dan mengolah data, dan pada akhirnya menyimpulkan pemecahan terbaik dalam menyelesaikan masalah yang dihadapi.

Kegiatan yang dilakukan siswa dalam model inkuiri diawali dengan merumuskan masalah. merumuskan masalah merupakan langkah membawa siswa pada suatu persoalan yang mengandung teka-teki. Persoalan yang disajikan adalah persoalan yang menantang siswa untuk memecahkan teka-teki itu. Tekateki dalam rumusan masalah tentu ada jawabannya, dan siswa didorong untuk mencari jawaban yang tepat. Proses mencari jawaban itulah yang sangat penting dalam pembelajaran inkuiri, oleh karena itu melalui proses tersebut siswa akan memperoleh pengalaman yang sangat berharga sebagai upaya mengembangkan mental melalui proses berpikir. Sebagai contoh dalam penelitian ini pada pertemuan pertama untuk indikator menjelaskan algoritma pembagian suku banyak, siswa diberikan masalah berupa pertanyaan: "diantara bilangan berikut yang mana yang merupakan bentuk suku banyak dan yang mana yang bukan bentuk suku banyak" (guru mengajukan masalah bentuk perbandingan aljabar $5 x^{2}+7 x+6$ dan $\left.5 \mathrm{x}^{2}+7 \mathrm{x}+6 \mathrm{x}^{-1}\right)$.

Setelah memperoleh jawaban, maka siswa dapat merumuskan suatu kesimpulan.
Merumuskan kesimpulan adalah proses mendeskripsikan temuan yang diperoleh berdasarkan hasil pengujian hipotesis. Untuk mencapai kesimpulan yang akurat sebaiknya guru mampu menunjukkan pada siswa data mana yang relevan. Dalam masalah di atas siswa pada akahirnya dapat merumuskan kesimpulan bahwa bentuk umum suku banyak adalah bervariabel dan bererajat, dengan $a_{k}$ disebut koefisien $\mathrm{x}^{\mathrm{k}}$, koefisien $\mathrm{x}$ dengan pangkat tertinggi disebut dengan koefisien utrama, a disebut konstanta, dan untuk $a_{0} \neq 0$ maka suku banyak tersebut berderajat $n$.

Model masyarakat belajar juga memiliki keunggulan yaitu mengharapkan siswa dalam belajar secara kelompok dalam suasana sosial yang berkaitan dengan konteks kehidupan sosial sebenarnya. Dengan pembelajaran masyarakat belajar umumnya siswa lebih diarahkan pada suatu proses kerjasama dalam memecahkan masalah secara bersama-sama. Inti dari model ini adalah kerjasama dalam kehidupan sosial.

Selain kerjasama, tujuan lain pembelajaran masyarakat belajar adalah adanya kolaboratif. Kolaboratif adalah cara mengajarkan kepada siswa keterampilan kolaborasi. Kerjasama dan kolaborasi merupakan dua keterampilan penting untuk dimiliki di dalam masyarakat di mana banyak kerja orang dewasa sebagian besar dilakukan dalam organisasi yang saling bergantung satu sama lain dalam masyarakat yang memiliki ragam budaya berbeda. Sebagai contoh dalam penelitian ini untuk perlakuan pertama pada tahap awal siswa langsung diminta untuk berkelompok dan menyelesaikan masalah tentang variabel bentuk suku banyak dan bukan suku banyak, berbeda dengan model inkuiri pada kegiatan inti model masyarakat belajar siswa tidak diminta membandingkan antara kedua variabel, tetapi siswa langsung diminta memecahkan masalah dengan penjumlahan dan perkalian suku banyak dari variabel yang diberikan, dalam hal ini siswa memecahkan masalah bersama-sama dan saling berdiskusi, kemudian dilanjutkan dengan persentase dan membandingkan jawaban dengan kelompok lainnya, soal yang diberikan tidak sama untuk masing-masing kelompok, tetapi pada akhirnya siswa menemukan cara yang paling efektif untuk memecahkan persoalan yang diberikan yang merupakan hasil akhir dari suatu kesimpulan dalam pemecahan masalah. 
Meski model inkuiri dan model masyrakat belajar memiliki kelebihan masingmasing, namun dalam pembelajaran matematika khususnya dalam kompetensi dasar menggunakan teorema sisa dan teorema faktor dalam pemecahan masalah kebutuhan siswa dalam belajar untuk kompetensi dasar ini lebih mengutamakan pemecahan masalah yang intinya harus dilalui dalam rangkaian kegiatan pemecahan masalah melalui aktivitas siswa secara maksimal untuk mencari dan menemukan. Pada dasarnya tiap model selain memiliki keunggulan juga memiliki kelemahan, ini dibuktikan dengan tetap adanya siswa yang memperoleh skor rendah berdasarkan tes hasil belajar dalam penelitian ini. Bedasarkan observasi selama peneltian berlangsung dapat disimpulkan bahan untuk model pembelajaran inkuiri, baik siswa maupun guru kurang memiliki kesiapan mental dalam mengikuti model ini, selain itu pembelajaran ini kurang berhasil dalam kelas besar, misalnya sebagian waktu hilang karena membantu siswa menemukan teori-teori atau menemukan bagaimana bentuk kata-kata atau menyatakan suatu variabel tertentu dalam memberikan suatu kesimpulan yang berkenaan dengan teori akhir dari penemuan yang dilakukan, hal lain adalah harapan yang ditumpahkan pada model ini mungkin mengecewakan siswa yang sudah biasa dengan perencanaan dan pembelajaran secara tradisional jika guru tidak menguasai pembelajaran inkuiri, dengan alasan-alasan ini maka hasil belajar beberapa siswa juga masih dibawah rata-rata dari apa yang diharapkan dalam keberhasilan pembelajaran ini.

Namun demikian berdasarkan hasil penelitian dapat diketahui bahwa model pembelajaran inkuiri maupun masyarakat belajar menempatkan siswa sebagai subjek belajar, bukan hanya sebagai pendengar, tetapi mereka berperan untuk menemukan sendiri inti dari materi pelajaran itu sendiri, selain itu aktivitas ini juga diharapkan dapat diharapkan dapat menumbuhkan sikap percaya diri (selfbelief) pada diri siswa. Hal ini sesuai pula dengan teori yang dikemukakan oleh Joyce dan Weil (2009) bahwa belajar dengan cara menemukan sendiri dapat dipercaya dalam mengembangkan kemandirian, anak-anak mempunyai rasa ingin tahu untuk tumbuh, belajar dengan menemukan merupakan bekal dalam menggali semangat anak, memberikan bimbingan secara khusus sehingga mereka dapat memahami suatu gagasan yang lebih luas.
Hasil penemuan ini juga sesuai dengan teori yang dikemukakan olah Bruner dalam Hasibuan dan Moejiono (1993) yang mengemukakan bahwa pencarian (inkuiri) mengandung makna sebagai berikut: (1) dapat membangkitkan potensi intelektual siswa karena seseorang hanya dapat belajar dan mengembangkan pikirannya jika ia menggunakan potensi inlelektualnya untuk berpikir; (2) siswa yang semula memperoleh extrinsic reward dalam keberhasilan belajar (mendapat nilai yang baik), dalam pendekatan inkuiri akan dapat memperoleh intrinsic reward (kepuasan diri), (3) siswa dapat mempelajari heuristik (mengolah pesan atau informasi) dari penemuan, artinya bahwa cara untuk mempelajari teknik penemuan ialah dengan jalan memberikan kesempatan kepada siswa untuk mengadakan penelitian sendiri, dan (4) dapat menyebabkan ingatan bertahan lama sampai internalisasi pada diri siswa.

Hasil penelitian ini juga mendukung penelitian sebelumnya yang dilakukan oleh Darajat (2004) mendapatkan kesimpulan bahwa metode pembelajaran discoveri dengan bimbingan lebih efektif digunakan dari pada metode masyarakat belajar dalam meningkatkan hasil belajar fisika siswa. Hasil penelitian yang dilakukan oleh Dewi (1999) mengemukakan bahwa keberhasilan menemukan sendiri dapat menimbulkan rasa puas dan gembira pada diri siswa yang akhirnya menimbulkan rasa ingin belajar sendiri dan menimbulkan daya kreativitas siswa. Hasil penelitian ini juga sesuai dengan temuan Mukhadis (2003) dalam penelitiannya yang menunjukkan pengaruh latihan inkuiri terhadap prestasi belajar tipe prosedural, di mana hasil penelitiannya menemukan bahwa kelebihan latihan inkuiri dalam meningkatkan hasil dan transfer belajar, yakni pengenalan pola, urutan tindakan dan gabungan keduanya disebabkan adanya penerapan empat macam komponen model yaitu urutan latihan inkuiri, urutan prasyarat belajar, rangkuman dan sintesis yang secara sistematis tidak terdapat dalam model urutan linier bertahap. Keempat macam komponen model ini memiliki potensi untuk memudahkan proses penstrukturan pengalaman belajar isi prosedural dalam proses pembentukan struktur kognitif baru.

Hasil penelitian menunjukkan bahwa rata-rata hasil belajar Matematika siswa yang memiliki gaya belajar visual lebih tinggi daripada hasil belajar matematika siswa yang 
memiliki gaya belajar auditorial. Selanjutnya dalam penelitian ini juga terbukti bahwa hasil belajar matematika siswa yang memiliki gaya belajar visual yang diajar dengan Model pembelajaran inkuiri lebih tinggi daripada hasil belajar matematika siswa yang diajar dengan Model pembelajaran masyarakat belajar. Hal ini mengindikasikan bahwa siswa yang mempunyai gaya belajar visual lebih mampu memahami bahan pelajaran matematika dibandingkan siswa yang mempunyai gaya belajar auditorial. Penelitian ini juga membuktikan bahwa siswa yang memiliki gaya belajar visual lebih cocok diajar dengan menggunakan Model inkuiri. Pembelajaran dengan Model inkuiri sangat tepat dibandingkan model pembelajaran masyarakat belajar untuk diterapkan pada siswa yang memiliki gaya belajar visual.

Siswa yang memiliki gaya belajar visual adalah siswa yang memiliki ciri-ciri antara lain sebagai berikut : (a) rapi dan teratur; (b) perencana dan pengatur jangka panjang yang baik; (c) teliti terhadap detail; (d) mementingkan penampilan, baik dalam hal pakaian maupun presentasi; (e) pengeja yang baik dan dapat melihat kata-kata yang sebenarnya dalam pikiran mereka; (f) mengingat apa yang dilihat, daripada yang didengar; (g) mengingat dengan asosiasi visual; (h) biasanya tidak terganggu oleh keributan; (i) mempunyai masalah untuk mengingat instruksi verbal kecuali jika ditulis, dan seringkali minta bantuan orang untuk mengulanginya; (j) pembaca cepat dan tekun; (k) lebih suka membaca daripada dibacakan; membutuhkan pandangan dan tujuan yang menyeluruh dan bersikap waspada sebelum secara mental merasa pasti tentang suatu masalah atau proyek; (1) mencoret-coret tanpa arti selama berbicara di telepon dan dalam rapat; (m) lupa menyampaikan pesan verbal kepada orang lain; (n) sering menjawab pertanyaan dengan jawaban singkat ya atau tidak; (o) lebih suka melakukan demonstrasi daripada berpidato; dan (p) lebih suka seni daripada musik.

Kesimpulan penelitian ini juga mendukung teori yang dikemukakan dikemukakan oleh dePorter dan hernacki (1992) bahwa ciri-ciri tersebut antara lain:(1) Orang orang Visual mempunyai ciri-ciri, rapi dan teratur; berbicara dengan cepat; perencana dan pengatur jangka panjang yang baik; teliti terhadap detail; mementingkan penampilan, baik dalam hal pakaian maupun presentasi;pengeja yang baik dan dapat melihat kata-kata yang sebenarnya dalam pikiran mereka; mengingat apa yang dilihat, daripada yang didengar; mengingat dengan assosiasi visual; biasanya tidak terganggu oleh keributan; mempunyai masalah untuk mengingat instruksi verbal kecuali jika ditulis, dan seringkali minta bantuan orang untuk mengulanginya; pembaca cepat dan tekun; lebih suka membaca daripada dibacakan; membutuhkan pandangan dan tujuan yang menyeluruh dan bersikap waspada sebelum mental merasa pasti tentang suatu masalah atau proyek; mencoret-coret tanpa arti selama berbicara di telepon dan dalam rapat;lupa menyampaikan pesan verbal kepada orang lain; sering menjawab pertanyaan dengan jawaban singkat ya atau tidak; lebih suka melakukan demonstrasi daripada berpidato; lebih suka seni daripada musik

Hasil penelitian ini juga mendukung penelitian sebelumnya yang dilaporkan oleh Sinaga (2007) yang menyatakan hasil belajar mahasiswa yang memiliki gaya belajar visual, auditorial dan kinestetik berbeda secara signifikan, yaitu hasil belajar kebutuhan dasar manusia I mahasiswa Akper Langkat untuk mahasiswa yang memiliki gaya belajar kinestetik lebih tinggi dibandingkan hasil belajar mahasiswa yang memiliki gaya belajar visual dan auditorial.

Temuan penelitian menunjukkan bahwa terdapat interaksi antara Model pembelajaran dan gaya belajar terhadap hasil belajar matematika siswa. Siswa yang memiliki gaya belajar visual yang diajar dengan model inkuiri lebih tinggi hasil belajar matematikanya daripada siswa yang memiliki gaya belajar auditorial yang diajar dengan model inkuiri. Demikian pula siswa yang memiliki gaya belajar auditorialyang diajar dengan model pembelajaran masyarakat belajar memperoleh hasil belajar matematika yang lebih tinggi daripada siswa yang memiliki gaya belajar visual dengan Model pembelajaran masyarakat belajar. Hal ini mengindikasikan adanya interaksi antara model pembelajaran dengan gaya belajar terhadap hasil belajar matematika siswa.

Siswa yang memiliki gaya belajar auditorial jika diajar dengan model pembelajaran inkuiri akan mengalami kesulitan untuk membangun atau mengkonstruk pengetahuan dan keterampilan matematika yang dibutuhkannya, sebab siswa dengan gaya belajar auditorial memiliki tingkat kecepatan yang rendah dalam menyelesaikan soal-soal 
matematika. Pembelajaran inkuiri menuntut kemampuan dalam menyelesaikan soal-soal secara rinci, terurut, dan sistematis. Sebaliknya siswa yang memiliki gaya belajar auditorial akan mudah belajar dengan menggunakan model pembelajaran masyarakat belajar, karena model ini mengarahkan siswa pada sejumlah informasi yang membawa mereka memhami situasi sosial yang ada disekelilingnya.

Hasil penelitian ini mendukung penelitian sebelumnya yang dikemukakan oleh Sutrisno (2006) yang mengemukakan bahwa siswa yang memiliki gaya belajar visual jika dibelajarkan dengan model latihan inkuiri memperoleh hasil belajar kimia yang lebih tinggi dibandingkan dengan jika dibelajarkan dengan model konvensional. Sebaliknya, siswa yang memiliki gaya belajar auditorial jika dibelajarkan dengan model konvensional memperoleh hasil belajar kimia yang lebih tinggi dibandingkan dengan jika dibelajarkan dengan model latihan inkuiri.

\section{PENUTUP \\ Simpulan}

Berdasarkan hasil penelitian dan pembahasan yang dikemukakan sebelumnya, maka dapat simpulakan bawah :

1. Hasil belajar matematika siswa yang diajarkan dengan model inkuiri lebih tinggi dibandingkan dengan hasil belajar matematika siswa yang diajarkan dengan model pembelajaran masyarakat belajar.

2. Hasil belajar matematika siswa yang memiliki gaya belajar visual lebih tinggi daripada siswa yang memiliki gaya belajar auditorial.

3. Terdapat interaksi antara model pembelajaran dan gaya belajar yang memberikan perbedaan pengaruh terhadap hasil belajar matematika siswa. Perbedaan pengaruh tersebut adalah: (1) Hasil belajar matematika siswa dengan gaya belajar visual yang diajar dengan model inkuiri lebih tinggi daripada hasil belajar siswa dengan model pembelajaran masyarakat belajar; (2) Hasil belajar matematika siswa dengan gaya belajar visual yang diajar dengan model inkuiri lebih tinggi daripada hasil belajar siswa dengan gaya belajar auditorial yang diajar dengan model pembelajaran inkuiri; (3) Hasil belajar matematika siswa dengan gaya belajar visual yang diajar dengan pembelajaran inkuiri lebih tinggi dari hasil belajar siswa dengan gaya belajar auditorial yang diajar dengan model pembelajaran masyarakat belajar; (4) Hasil belajar matematika siswa dengan gaya belajar auditorial yang diajar dengan model inkuiri lebih tinggi daripada hasil belajar siswa dengan gaya belajar auditorial yang diajar dengan model pembelajaran masyarakat belajar; (5) Hasil belajar matematika siswa dengan gaya relajar visual yang diajar dengan model masyarakat belajar lebih tinggi daripada hasil belajar siswa dengan gaya relajar auditorial yang diajar dengan model pembelajaran masyarakat belajar; dan (6) Hasil belajar matematika siswa dengan gaya belajar auditorial yang diajar dengan model pembelajaran masyarakat belajar lebih tinggi daripada hasil belajar siswa dengan gaya belajar auditorial yang diajar dengan model pembelajaran inkuiri.

\section{Saran}

Materi pelajaran matematika yang bersifat realistik, logis dan memerlukan tahapan-tahapan ilmiah dalam kegiatan pembelajaran yang dilaksanakan, disarankan bagi guru untuk menggunakan model pembelajaran inkuiri ini agar hasil belajar matematika siswa tersebut lebih tinggi, karena inkuiri sangat sesuai dengan pembelajaran matematika.

Berdasarkan hasil penelitian ini diketahui hasil belajar siswa yang dibelajarkan dengan model inkuiri pada pembahasan algoritma suku banyak lebih tinggi daripada masyarakat belajar, meskipun perbedaan itu tidak terlalu signifikan. Oleh karena itu disarankan pada guru matematika untuk dapat menerapkan kedua model pembelajaran ini dalam menyampaikan materi matematika dengan catatan harus disesuaikan dengan karakteristik siswa.

Untuk meningkatkan hasil belajar matematika siswa yang memiliki gaya belajar visual, model pembelajaran inkuiri ini sebagai salah satu alternatif yang sesuai dengan karakteristik siswa tersebut, di samping itu dengan model pembelajaran ini siswa akan lebih terlatih dan terbiasa bekerja sama untuk menyelesaikan permasalahannya demikian juga disarankan bagi guru untuk menggunakan model pembelajaran inkuiri untuk membelajarkan siswa yang memiliki gaya belajar auditrorial agar hasil belajarnya lebih tinggi. 
Pengunaan model pembelajaran yang sesuai dengan karakteristik siswa dan materi pelajaran memberi pengaruh pada hasil belajar siswa. Oleh sebab itu disarankan bagi kepala sekolah untuk melatih guru-guru dalam pemilihan model pembelajaran dan meningkatkan pengawasan pelaksanaan pembelajaran siswa di kelas. Dalam hal ini salah satu hasil penelitian yang mampu meningkatkan hasil belajar matematika siswa dengan penggunaan model pembelajaran inkuiri bagi siswa yang memiliki gaya belajar visual.

Populasi dan sampel yang dilibatkan pada penelitian jumlahnya kecil, untuk itu disarankan bagi peneliti lain untuk melakukan penelitian lanjut yang jumlah populasi dan sampelnya lebih besar.

Guna penelitian lanjutan pada penerapan model pembelajaran di samping kepada guru yang menjadi mitra peneliti, perlu disosialisasikan juga terlebih dahulu kepada siswa bagaimana mekanisme model pembelajaran inkuiri ini dan apa yang perlu dan yang tidak perlu dilakukan agar saat pembelajaran berlangsung kejanggalan dan kekakuan dalam proses pembelajaran dapat diminimalkan.

\section{DAFTAR PUSTAKA}

Anglin, G.J. (1991). Instructional Technologi, past, present, future. Engelwood Colorado: Librarias Unlimited, Inc.

Bloom, B.S. (1985). Taxonomy of Educational Objectives. Handbook 1: Cognitive domain. New York: David McKay

Dahar, R.W. (1989). Teori-teori Belajar. Jakarta: Erlangga

Degeng. S.N.I. (1989). Ilmu Pengajaran Taksonomi Variabel. Jakarta: Proyek Pengembangan Lembaga Pendidikan Tenaga Kependidikan Departemen P dan $\mathrm{K}$.

Devito, J.A. (2002). The Interpersonal Communication Reader. New York: Allyn and Bacon.

Dick , W. , Carey, L., and Carey, J.O. (2005). The Systematic Design of Instruction (Edisi II). USA: Scott, Foreman.

Gagne. (1979). Principles of Instructional Design, Second edition. New York: Holt Rinehart and Winston
Joyce, B. dan Weil, M. (1996). Models of Teaching. Englewood Cliffs, New Jersey: Prentice-Hall Inc.

Littelwood, W. (1983). Communicative Langunge Teaching and Instruction. London: Cambridge University Press.

Mulyasa. (2007). Menjadi Guru Profesional Menciptakan Pembelajaran yang Kreatif dan Menyenangkan. Bandung Remaja Rosdakarya.

Nasution, S. (1991). Teknologi Pendidikan. Bandung: Jemmars

Rahmad, J. (2001) Psikologi Komunikasi. Bandung: Remaja Rosadakarya

Reigeluth, C.M. (1983). Instructional Design Theory of Pendekatans: An Overviuw of the their Current Status. London: Prentice Hall

Romizowski, A.Z. (1981). Designing Instructional System. New York: Nichol Publishing Company.

Rostiyasah (2001). Strategi Belajar Mengajar. Jakarta: Bina Aksara

Sadiman, A. M. (2003), Interaksi dan Motivasi Belajar Mengajar. Jakarta : Raja Grafindo Persada

Sadtono. (1987) Antologi Pembelajaran Bahasa Asing Khususnya Bahasa Inggris. Jakarta: P2LPTK

Sakholid. (2005). Analisis Konstraktif Bahasa Arab dan Bahasa Indonesia. Jakarta

Sanjaya, W. (2007). Strategi Pembelajaran Berorintasi Standar Proses Pendidikan. Jakarta: Kencana Prenada Media Group

Snellbecker, Glen E. (1974). Learning Theory Instructional Theory and Psychoeducational Design. New York: $\mathrm{Me}$, Graww-Hill Inc.

Suprayekti. 2003. Interaksi Belajar Mengajar. Jakarta: Departemen pendidikan Nasional

Shell, B. C dan Richey, R.C. (1994). Instuctional Technology the Defenition and Domains of the Filed. Washington: terjemahan Yusuf Hadi Miarso, dkk.

Syah, M. (1999). Psikologi Belajar. Jakarta: Logos Wacana Ilmu

Winkel. W.S. (2007). Psikologi Pengajaran. Yokyakarta: Media Abadi. 